\title{
The Russian manor interior in the context of the West-and-East
}

\author{
cross-cultural dialogue
}

\author{
Natalia Bondarenko \\ Department of Open Educational Technologies \\ Moscow Institute of Open Education \\ Moscow, Russia
}

\begin{abstract}
This article presents the particular characteristics of the Russian manor culture sprang up in the latter half of the $18^{\text {th }}$ century. It states that the phenomena of the Russian manor is that it represented a whole world - a «microcosm», uniting within itself a house, a garden, a forest and a man. The most of the focus is posed on the country house interior, with the descriptions of the principal rooms of the manor: man's study, drawing room, woman's cabinet, portrait room, demonstrating the mix of the traditions of West and East. The article shows that that peculiarity of the Russian culture consisted in its particular sensibility to foreign influences. Through their creative conversion of the achievements of the West and East, on the one hand, and relying upon the domestic traditions, on the other, the artists composed inimitable examples of interiors and decors.
\end{abstract}

Keywords - cross-cultural dialogue; inretcultural dialoque; interior; Russian manor; Chinese porcelain; landscape

\section{INTRODUCTION}

There is a plafond named «The Union of Europe and Asia» in one of the halls of the Russian Emperors' summer residence in Oranienbaum. It represents a wedding: the betrothal of a girl dressed as a European and a young man in a Chinese costume. There are invitees to the right and to the left of them. This was an allegoric view of the West-and-East dialogue represented by a European.

The cross-fertilization of the two civilizations - the Western and the Eastern - reached its utmost development at the Modern Age (18th - first third of the 19th century). For Russia that was a period of self-identification: keeping its orientation over the authority of the West in the fields of urban development, music, philosophy, education and guidance, and at the same time discovering the mysterious East, Russia perceived itself through the mirrors of other cultures and its dialogue with them.

Laic artistic culture existent in Russia till the 18th century in the form of folklore experienced wide influence of the Western traditions at the Petrine times. It was the youngest among the cultures of the European civilization, and it needed to work its way of accelerated evolution. It was the period of utmost demonstration of the Russian man's capacity to perceive the achievements of the previous civilizations in a creative manner. Thus, on the basis of dialogue, there developed within the Russian culture the synthesis of invected elements of the artistic thinking and the domestic experience.

\section{Establishment OF THE ACtive DiALOGUE WITH THE WeST AND THE EAST - REIGN OF PETER THE $1^{\text {ST }}$}

The Russia's entry into the cultural dialogue with the West and the East dates of the times of Peter the Great (1672-1725). For the purposes of founding the imperial capital there had been invited: the French architect J.B. Leblon (1679-1719), Domenico Tresini (1670-1734) originated from the Southern Switzerland; Francesco Bartolomeo Rastrelli (1700-1771), Italian, and other foreign architects.

That was also the time of conversance with the Eastern culture: number of legations sent to Beijing had been welcomed by the Emperor Xuanye, which was meant to prove his sympathy to the Russian tzar.

The Emperor Peter the 1st, while visiting the European countries - Prussia, Czechia, Holland, Enmland - examined the residences of the European monarchs. That was under the influence of the Vienna Palace's Chinese Room that the Green Study had been constructed in the Summer Palace of the Russian Emperor, which interior contained a lot of Chinese decorations and porcelain.

\section{THE «CHINOISERIE» PHENOMENON - IMITATION OF THE CHINESE STYLE}

It is to be noted that the barocco style then prevailing and reflecting the perceptions of unity, diversity, inconstancy and permanent motion of the world, had represented the human being as a complex multidimensional personality. Dynamism, light and shade contrasty, combination of reality and fantasy all of this found its reflection in the interiors of series of palaces and gardens of Saint Petersburg, Peterhof and Tsarskoye Selo. This is why, in Russia as well as in Europe, unsurprisingly arises a particular interest to all that is exotic, and there finds its beginning the cultural tradition known as «chinoiserie» - imitation of the Chinese style. One of the most striking examples of «chinoiserie» is the Chinese style decoration of several cabinets of the Russian Emperors' summer residence, the Oranienbaum.

Walls of the Small Chinese Cabinet and the Large Chinese Room are decorated with the embroideries depicturing exotic birds, butterflies and plants expressly made for the palace by the Russian mistresses of golden embroidery. The decorations were completed by the objects of handiwork - pieces of red 
lacquer, porcelain and bronze figurines of Chinese gods, Lui Dunbin and Zhunli, Shou-Xing, caskets, china floor vases. The fashion for the Eastern decorations penetrates from the imperial palaces to summer country houses - manors of the Russian nobility and aristocracy.

\section{ART OF THE MANOR - PHENOMENON OF THE RUSSIAN CULTURE}

In 1762 the Emperor Peter III (reign 1761-1762) issued the edict overslaughing the nobility from the compulsory military service; then the majority preferred to retire from their national service and settle down in the country.

There existed two kinds of manor: manor as an economic center, comprising household outbuildings and nobleman's dwellings, and manor as a place of entertainment of the Russian aristocracy, the most renowned whereof were the palaces of count Sheremetev, prince Yusupov, princes Golitzyn, etc.

\section{A. Exclusive microworld of the Russian manor}

The phenomena of the Russian manor was that it represented a peculiar microworld: a house, a garden, a river/pond, a man - all of it harmoniously entwined to a unique space. The classical architecture of the house correlated with the midland landscape. That was why the buildings were paint in warm colors: golden, yellow, reddish. It was as though they conflowed with the surrounding nature and created together a beautiful landscape. The metaphor of the manor's chronotope based upon the idea of the «circle of life»: indeed, the manor represented to the nobleman the «morning» and the «fall» of his life for more than two centuries.

\section{B. Traces of the European influence in the manor's interior}

The principal rooms of the house were the drawing room and the dining room, where visitors were received. The prevailing colors of the drawing room interior were sky-blue, white and greenish. Marble sculptures by French or Italian artists, glitter of chandeliers and numerous mirrors in golden frames served to outline the solemnity of the room.

The decisive influence of the European court style manifested itself in the great hall of the Russian manor. Towards the middle of the 18th century, the dining room became imperative for the royal courts and served to the aristocracy as a model to emulate.

According to the European traditions, they stopped decorating walls with silk tissues in the Russian manors, as smells soaked into them. Thence, there were paintings and pictures on the walls. Following the Western tradition, they placed family portraits and household heirlooms in the dining rooms. There was little furniture there: tables, chairs, small buffets with objects of glass.

\section{Traces of the Chinese influence}

A particular place in the decoration of the dining room pertained to porcelain. Eastern vases and plates were highly prized by the nobility. Admiration of exquisite pieces of the Song (960-1279) and Ming (1368-1644) periods proved to be a kind of reaction to the splendor and decorativeness of the
18 th century.

It is well known that the Chinese art (landscapes, in the first place), based on the philosophy of Tao and Confucius, proclaimed man's internal self-sufficiency, his openness to the world, encouraged the aspiration to live in harmony with the nature. According to the Tao philosophy, the truth cannot be expressed with words, there is the only way - contemplation, enabling to find the truth in one's own self. «The Tao is vague and uncertain». "The utmost virtue is like water. Water behooves to all creatures and does not fight. It belongs where people wouldn't like to».

The philosophers perceived the nature not only as a place of purification and spiritual rise, but also as the one where man retrieves its soul lost in the world bustle. Such a landscape created aesthetic sensations and deep emotions. It is to be noted that the «art of the Path» originating from the ancient Chinese idea sounded very consonant to a Russian soul.

Landscape - the shan-shui genre - better reflected the stylistic unity, it represented more than a depiction of the nature, this was a vision of the universe as a harmonical ensemble, laying emphasis on the interaction of the man and the nature.

The «Flowers-birds» genre made the man approach the natural world, sensitively catching each breath of the wind and leaves. Landscapes «mountains-waters» on the artists' vases reminded of the tranquil pleasures of solitude and contemplation of the nature, and imparted peace. The nobleman's glance passed from the Chinese artists' paintings to the landscapes of gardens, ponds and parks of the manor. Images engendered profound thoughts about the deepest stream of life, the spent time and the outlooks for the better.

\section{Interior of the essential elements of thet manor house}

The intellectual and household center of the house was the man's study. Its furnishing was ascetic: simple table clocks, desks, bureaus, easels. There were almost no pieces of decorative art, though genre paintings could be seen on the walls, reminding the master of the days of his youth.

The most important part of the study was the library. Books were indispensable in the master's day-to-day work: diplomatic codes, French novels, works on art, calendars comprised advice and recipes for all occasions. That was the place of origin of the manor's reading phenomenon.

Country houses often made place for an agreeable pastime. Thence the masters tended to assemble there considerable collections, making the source of their pride. Thus for instance, there was a large collection of Western-European paintings in the Arkhangelskoye manor belonging to the princes Yusupov.

Still, the snug homely atmosphere of the house derived from the woman's care. Women were excluded from the world of official service, and as a result their role in the nobility's living grow of importance, while «the culture was fully handed out to them» [2; 48]. Wives and mothers, women not only ran the household, but also formed the spiritual world of the house as family tutoresses. 
Among the private rooms, the woman's cabinet should be noted. Apart from practices in music and painting, the cabinet served for receiving close friends and neighbors. It mostly ensued at the tea parties, which subsequently became a good tradition of the Russian hospitality.

It is known that for the Eastern people the tea-drinking ceremony made a part of the contemplative attitude towards the nature and it involved reflections on the man and its relationship with the outside world. In contrast to the Chinese tradition, the Russian one focused on communion, exchange of ideas, careless conversations on general topics.

The decisive role in the creation of the cabinet belonged to the artistic furniture. Since the first quarter of the 19th century, they introduced into mansion houses the furniture made of the domestic karelian birch. The mistress could compose the interior by herself, making it look expressive and exquisite. Use of that kind of wood constituted the originality of the Russian school.

It is to be noted that Chinese lacquer manufactures were very popular in Russia. Russian artisans «unriddled» the secret of the Eastern artists, and by transforming foreign experience they established famous centers of miniature lacquer painting - Palekh and Mstera, places of production of the lacquer caskets and brooches well renowned throughout the world.

Theatre and music made an important part of the day-today life in the nobility's manors. Private theatricals took place in the specifically designated chambers, summer performances were played off in the open air, in the park. The count P.B. Sheremetev's manor Kuskovo was particularly famous for its theatrical spectacles. Ballets and operas were staged there. In the ambience of intimacy and quietness of the country manor flowered homely music-making, performed in particular «musical» drawing rooms.

\section{CONCLUSION}

In summary, it stands to mention that the manor culture established at the second part of the $18^{\text {th }}$ century represents a huge and interesting layer of the Russian culture evolution. The essential idea of the Enlightenment - superiority of the reason over the sense - was interpreted by the Russian artists in a specific way: most of them preferred the language of the art implying «hearty sensitiveness».

Naturally compiling examples of the Western and the Eastern culture, transforming the foreign experiences, they created in the country houses original pieces of interior (furniture, portraits, porcelains, etc.) in the context of national traditions. Through the assimilation of the experience of the Western and Eastern civilizations, with its particular perceptiveness to all foreign phenomena, Russia worked its way of introduction to the European space within a short time, and thus revealed to the world its authentic culture.

Nobility manors of the $18^{\text {th }}-$ first quarter of the $19^{\text {th }}$ century made sort of culture intercrossing centers, embodying the idea of cultural cross-fertilization between the West and the East.

\section{REFERENCES}

[1] Vdovin G. The world of Russian manor - the Russian manor myth // The world of Russian manor. Catalogue. Author-cataloguer V.A. Rakina. - M.: Avangard, 1995. - 144 c.

[2] Lotman Yu.M. Conversations about Russian culture: Life and traditions of the Russian nobility (XVIII - beginning of the XIX century). St.Petersburg.: Isskustvo, 1994. - 399 p.

[3] Bulavina D., Rozantseva S., Yakimchuk N. Arkhangelskoe. - M., Sovetskaya Rossia, 1983. 